\title{
Correlations between temporary teeth and functional treatment in mixed dentition - case presentation
}

\author{
Corelații între statusul dinților temporari și tratamentul funcțional \\ în dentația mixtă - prezentare de caz
}

\author{
Alexandrina Muntean', Sorina Sava², Mariana Păcurar ${ }^{3}$, Ada Gabriela Delean ${ }^{4}$ \\ ${ }^{1}$ Disciplina Pedodonție, Universitatea de Medicină și Farmacie „Iuliu Haţieganu“, Cluj-Napoca, România \\ ${ }^{2}$ Disciplina de Materiale Dentare, Universitatea de Medicină și Farmacie „Iuliu Haţieganu“, Cluj-Napoca, România \\ ${ }^{3}$ Disciplina de Ortodonție, Universitatea de Medicină, Farmacie, Științe și Tehnologie „G.E. Palade“, Tg. Mureș, România \\ ${ }^{4}$ Disciplina de Ododntoterapie, Universitatea de Medicină și Farmacie „Iuliu Haţieganu“, Cluj-Napoca, România
}

\begin{abstract}
Objectives. Orthodontic treatment intends to create a harmony between dental, muscular and osseous components. The purpose of this case presentation was to emphasize consequences of early loss of temporary teeth on dental-maxillary complex development.

Material and methods. 10 years old patient with dental movements following the early extraction of temporary teeth. The patient has habitual oral breathing associated with lower lip interposition.

Results. The functional treatment with twin-block appliance was chosen, taking into account the age-specific growth potential.

Discussions. Premature extraction of temporary teeth engenders lee-way-space loss, significant shortening and transverse constriction of the dental arch, elements aggravated by dysfunctions and parafunctions.

Conclusion. The early extractions performed during the growth period, through the associated dental migrations, determine growth changes with consequences on the functionality of the dento-maxillary apparatus.
\end{abstract}

Keywords: temporary teeth extraction, functional therapy, growth

\section{REZUMAT}

Obiective. Tratamentul ortodontic intenționează să creeze o armonie între componentele dentare, musculare și osoase. Scopul prezentării acestui caz a fost de a sublinia consecințele pierderii timpurii a dinților temporari asupra dezvoltării complexului dento-maxilar.

Material și metodă. Pacient în vârstă de 10 ani cu migrări dentare în urma extracției precoce a dinților temporari. Pacientul prezenta respirație orală habituală asociată cu interpunerea buzelor inferioare.

Rezultate. A fost ales tratamentul funcțional cu aparat twin-block, considerând potențialul de creștere specific vârstei.

Discuții. Extracția prematură a dinților temporari determină pierderea spațiului, scurtarea semnificativă și constricția transversală a arcadei dentare, elemente agravate de disfuncții și parafuncții.

Concluzie. Extracția precoce a dinților temporari în perioada de creștere, prin migrările dentare asociate, determină modificări ale creșterii, cu consecințe asupra funcționalității aparatului dento-maxilar.

Cuvinte cheie: extracție precoce, terapie funcțională, creștere 


\section{INTRODUCERE}

Anomaliile dento-maxilare includ în etiologia lor factori generali şi locali care influenţează direcțiile de creștere și dezvoltare ale aparatului dento-maxilar, elemente dirijate de către factorii genetici [1]. Dinţii şi arcadele alveolare se dezvoltă într-o poziţie de echilibru determinată de elementele musculare care delimitează culoarul dentar. Dezechilibrul grupelor musculare intra şi extraorale, consecutiv disfuncţiilor și parafuncțiilor (respiraţie orală, deglutiţie atipică, obiceiuri vicioase de interpunere hetero sau autotrope), poate influenţa direcţiile de creştere şi orientare ale arcadelor alveolodentare [1,2]. Leziunile odontale netratate ale dinților temporari, urmate de pierderea lor precoce, se constituie la rândul lor în elemente care perturbă creșterea, determină migrări dentare cu pierderea spațiului și apariția unor tulburări ocluzale, aducând un plus de dificultate în alegerea mijloacelor de tratament ortodontic [3]. Scopul acestui articol este de a ilustra, prin intermediul unui caz clinic, consecințele negative ale pierderii precoce a dinților temporari, într-un context disfuncțional, la un pacient aflat în perioada dentației mixte.

\section{PREZENTAREA CAZULUI}

Pacient de gen masculin, în vârstă de 10 ani, se prezintă cu solicitarea pentru tratament ortodontic consecutiv modificărilor fizionomice și funcționale observate de familie și pacient (fig. 1).

Se observă modificările de poziție și migrările dentare consecutive extracției precoce a dinților temporari din zona de sprijin ca element agravant al tabloului clinic. Examinările imagistice au completat datele furnizate de examenul clinic (fig. 2).

Se observă prezenţa tuturor mugurilor dinţilor permanenți de înlocuire şi de completare, precum și a tulburărilor de ordine și ritm de erupție. Teleradiografia de profil relevă un tipar scheletic normodivergent, profil retroarhial, clasa II scheletică și alveolară. Pacientul prezintă respirație orală habituală asociată unui obicei vicios de interpunere a buzei inferioare. În plus, dezechilibrul ocluzal a determinat apariția unei retracții gingivale la nivelul lui 31, igiena deficitară agravând statusul parodontal al pacientului.

Pentru a beneficia de potențialul de creștere specific pentru perioada a 2-a a dentației mixte, s-a decis abordarea terapeutică prin utilizarea unui aparat de tip Twin-Block cu anse pentru ingresiune aplicate la nivelul incisivilor centrali maxilari, ca o primă etapă de tratament ortodontic, după aplicarea măsurilor specifice de prevenție și profilaxie a cariei dentare, precum și a recomandărilor personalizate în ceea ce privește tehnica de periaj și alimentația cario-profilactică.

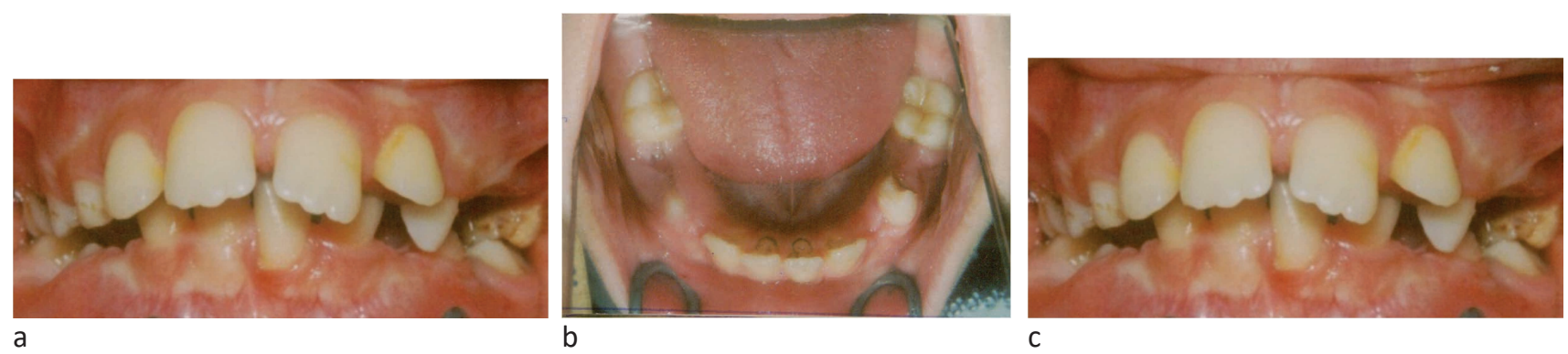

FIGURA 1. Aspectul arcadelor dentare $(a, b)$ și ocluzia la nivelul incisivilor (c) -aspect inițial
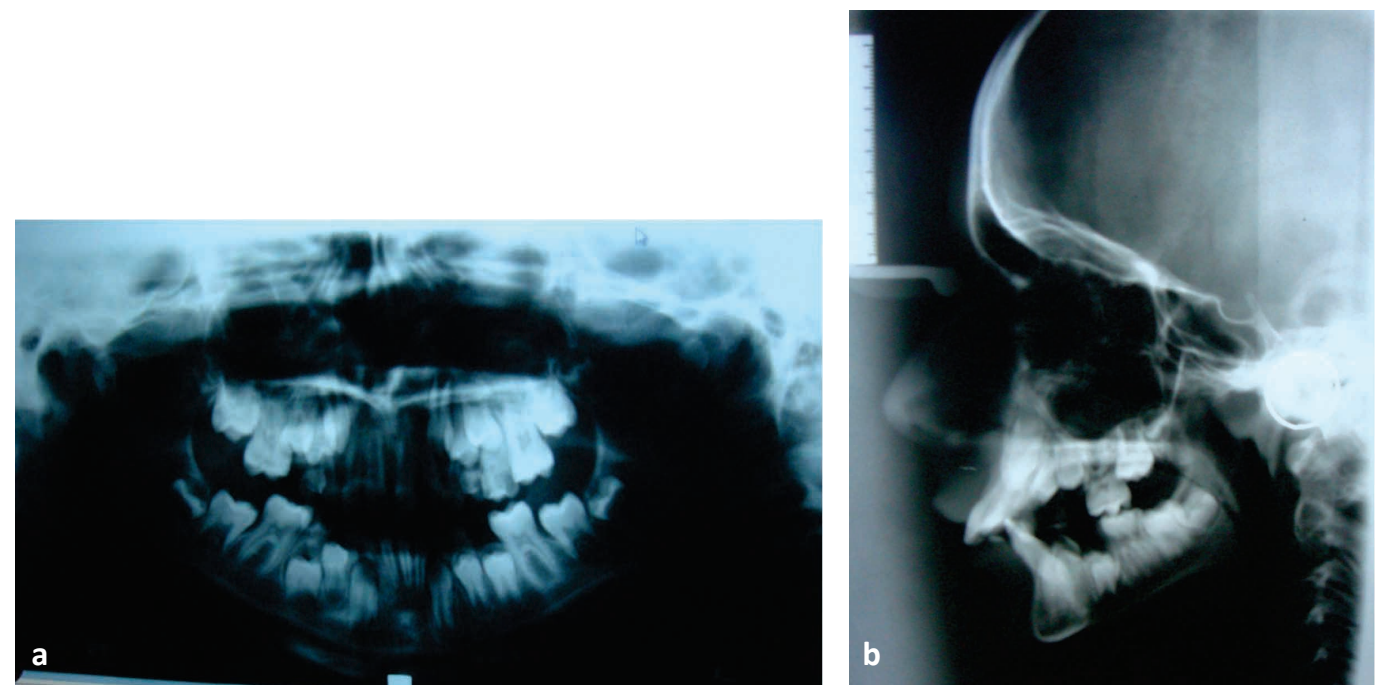

FIGURA 2

Ortopantomografia (a) și teleradiografia de profil (b) - aspect inițial 
După 2 luni, s-a observat închiderea diastemei, iar după 3 luni au fost corectate relațiile ocluzale la nivelul molarilor primi permanenți. După 5 luni de tratament, au fost suprimate ansele de ingresiune pentru a activa arcul vestibular în vederea retrudării grupui frontal superior, în contextul în care obiceiul vicios de aspirare a buzei inferioare a fost abandonat. La 11 luni de la începerea tratamentului, aspectul arcadelor dentare și al ocluziei au fost ameliorate și, astfel, procesul de erupție al dinților permanenți se va desfășura într-un context echilibrat (fig. 3 a-f).

\section{DISCUȚII}

Disfuncțiile și parafuncțiile determină în perioada dentației mixte o combinație de modificări ale scheletului, structurilor dento-alveolare și ale țesuturilor moi care modifică tiparul de creștere și dezvoltare. Extracția prematură a dinților temporari, fără gestionarea spațiului restant, determină pierderea lee-way-space-ului cu lipsa spațiului pentru încadrarea dinților succesionali permanenți, scurtarea semnificativă și constricția transversală a arcului dentar [3,4]. În cazul nostru, aceste elemente au fost agravate de existența tulburărilor de ordi- ne și ritm de erupție ale dinților permanenți asociate disfuncțiilor și parafuncțiilor. Un alt element neuro-muscular implicat în dezvoltarea aparatului dento-maxilar este considerat şi gradul de utilizare a unităților dentare în actul masticator [5]. Alimentaţia modernă din ce în ce mai puţin consistentă şi solicitantă determină reducerea dimensională a bazelor osoase, arcade alveolare înalte şi înguste și erupţie verticală excesivă a dinţilor, în special în regiunea anterioară. Aceste modificări apar drept răspuns la masticaţia realizată fără efort, ceea ce determină ca suturile superioare ale feţei să își exprime creșterea prea mult, în timp ce sutura mediană palatină creşte insuficient [6,7].

Distrucţia prin carie a feţelor meziale şi distale ale molarilor temporari sau pierderea acestora favorizează migrările dentare cu scurtarea arcadei. Pe lângă consecinţele dentare ale extracţiilor premature ale dinților temporari, întâlnim frecvent şi tulburări în dezvoltarea maxilarelor, în toate direcţiile spațiului: îngustare transversală, scurtare sagitală şi denivelarea accentuată a curbei Spee [8,9].

În acest context musculo-scheletal, printre diferitele strategii de tratament implementate pentru a trata pacienții, aparatul funcțional se consideră a fi

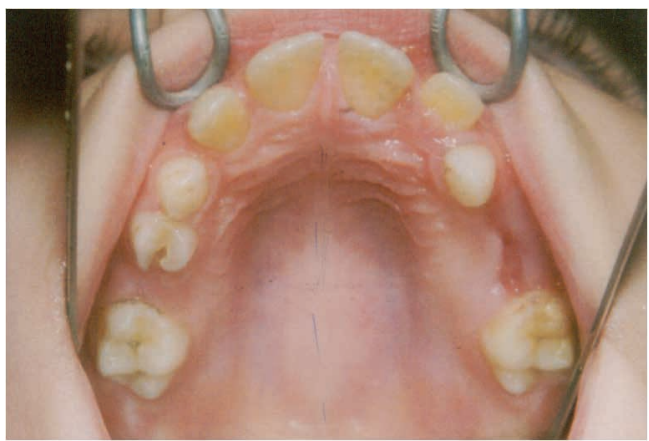

a

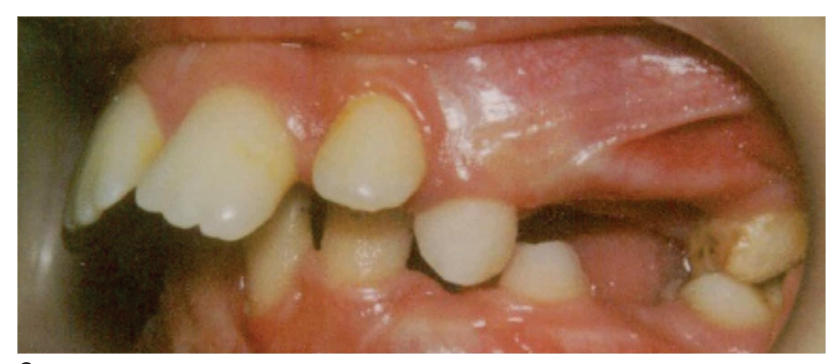

C

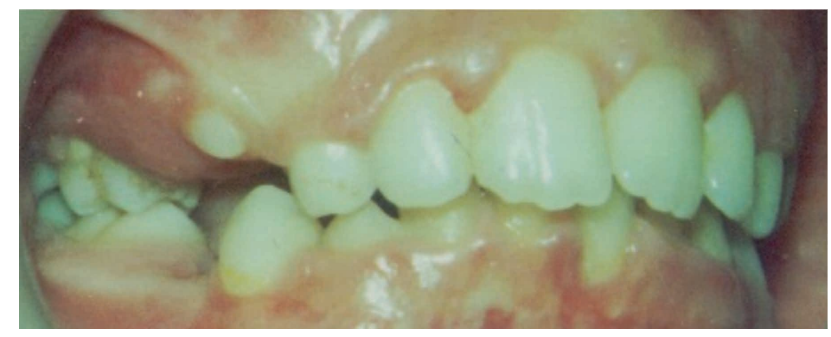

e

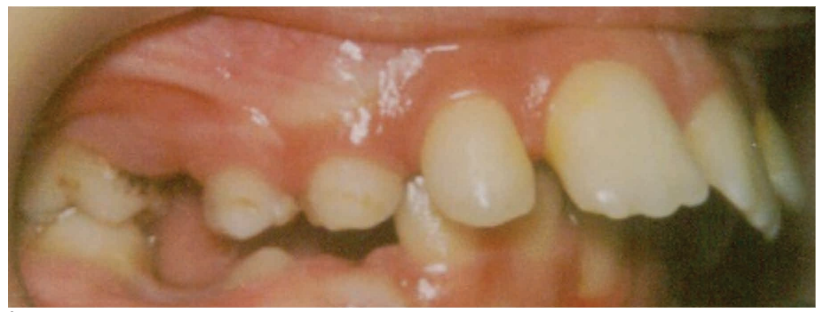

b
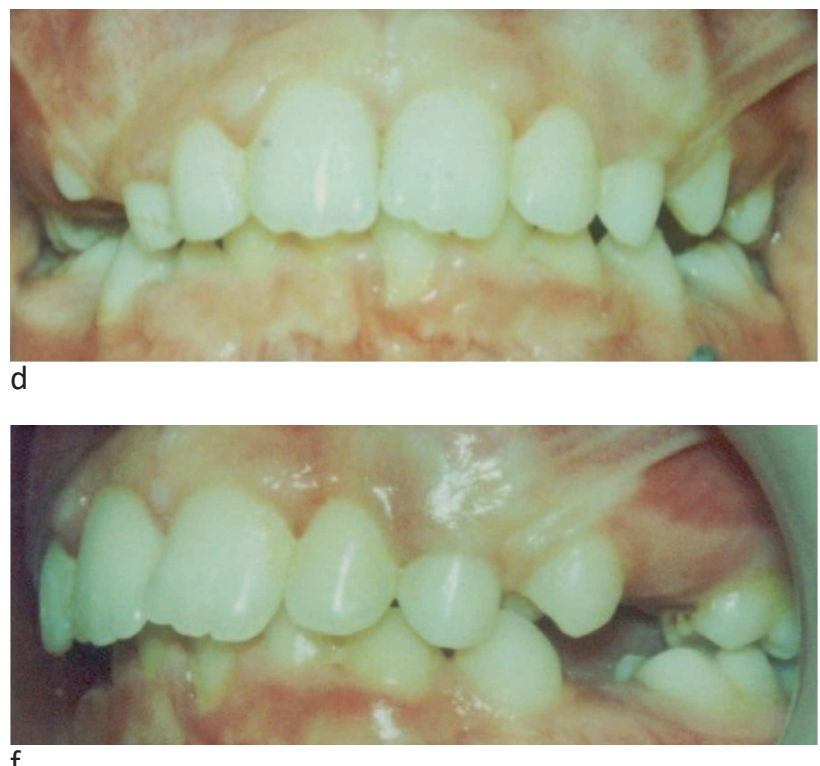

FIGURA 3a-f. Aspectul arcadelor dentare și ocluzia la nivelul incisivilor - aspect final 
opțiunea de elecție pentru periadele de creștere. Rezultatele obținute în acest caz au arătat că aparatul Twin-Block modificat poate fi utilizat ca opțiune de tratament printr-o combinație de modificări scheletice și efecte dentare în condiții de ancoraj deficitare. Trebuie menționat că măsurile de prevenție și profilaxie a cariei dentare trebuie să se adreseze atât dinților temporari, cât și dinților permanenți tineri, continuitatea arcadelor dentare și ocluzia echilibrată constituind elemente care previn apariția anomaliilor dento-maxilare [10,11].

Ortodonția interceptivă are drept scop corectarea unei malocluzii în curs de dezvoltare sau simplificarea tratamentului ortodontic ulterioar. Se consideră că anomaliile care se dezvoltă în dentiția mixtă pot fi corectate pe deplin cu măsuri interceptive simple în 15\% dintre cazuri sau situația se poate ameliora în 49\% dintre cazuri. Abordarea terapeutică în perioada dentației mixte are ca scop nu

\section{BIBLIOGRAFIE}

1. Fleming PS. Timing orthodontic treatment: early or late? Aust Dent J. 2017;62:11-19.

2. Taibah SM, Al-Hummayani FM. Effect of malocclusion on the self-esteem of adolescents. J Orthod Sci. 2017;6:123-128.

3. Bhujel N, Duggal MS, Saini P, Day PF. The effect of premature extraction of primary teeth on the subsequent need for orthodontic treatment. Eur Arch Paediatr Dent. 2016;6:423-434.

4. Vedovello SAS, de Carvalho ALM, de Azevedo LC, Dos Santos PR, Vedovello-Filho M, de C Meneghim M. Impact of anterior occlusal conditions in the mixed dentition on oral health-related quality-of-life item levels. Angle Orthod. 2020;4:564-570.

5. Tadic K, Katic V, Spalj S. Caries Experience of the Patients Referred for an Orthodontic Consultation. Acta Stomatol Croat. 2018;2:123-131.

6. D'anto V, Bucci R, Franchi L, Rongo R, Michelotti A, Martina R. Class II functional orthopaedic treatment: a systematic review of systematic reviews. Journal of Oral Rehabilitation. 2015;42:624-42.

7. Grippaudo C, Pantanali F, Paolantonio EG, Saulle R, Latorre G, Deli R. Orthodontic treatment timing in growing patients. Eur J Paediatr Dent. 2013;3:231-6.

8. Sharma DS, Srivastava S, Tandon S. Preventive orthodontic approach for functional mandibular shift in early mixed dentition: A case report. J Oral Biol Craniofac Res. 2019;2:209-14. doar îmbunătățirea esteticii, ci și stabilitatea pe termen lung și urmărirea procesului de erupție dentară, pentru a asigura o armonie perfectă între componentele dentare, musculare și osoase $[12,13]$.

\section{CONCLUZII}

Extracţiile precoce efectuate în perioada de creştere, prin migrările dentare asociate, determină modificări de creştere cu repercusiuni asupra funcționalității aparatului dento-maxilar (masticație, fizionomie, fonație, autoîntreținere).

Factorii disfuncționali se constituie în element de gravitate suplimentar pentru anomaliile dentomaxilare.

Statusul odontal al dinților temporari se constituie ca un element definitoriu pentru prognosticul și, mai ales, pentru posibilitatea aplicării măsurilor de tratament interceptiv sau precoce.

Conflict of interest: none declared Financial support: none declared

9. Lee KY, Park JH, Tai K, Chae JM. Treatment with Twin-Block appliance followed by fixed appliance therapy in a growing Class II patient. Am J Orthod Dentofac Orthop. 2016;150:847-63.

10. Marchiori GE, Sodre LO, da Cunha TC, Torres FC, Rosrio HD, Paranhos LR. Pleasantness of facial profile and its correlation with soft tissue cephalometric parameters: perception of orthodontists and lay people. Eur J Dent. 2015;9:352-5.

11. Pacheco-Pereira C, Pereira JR, Dick BD, Perez A, Flores-Mir C. Factors associated with patient and parent satisfaction after orthodontic treatment: a systematic review. Am J Orthod Dentofac Orthop. 2015;148:652-9.

12. Tsiouli K, Topouzelis N, Papadopoulos MA, Gkantidis N. Perceived facial changes of class II division 1 patients with convex profiles after functional orthopedic treatment followed by fixed orthodontic appliances. Am J Orthod Dentofac Orthop. 2017;152:80-91.

13. Baheti MJ, Toshniwal NG, Bagrecha SD. Oral health in orthodontic treatment: Preventive and innovative approach. J Dentofac Sci. 2014;3:39-46. 